\title{
SOIL MOISTURE MAPPING USING SMOS APPLIED TO FLOOD MONITORING IN THE MOROCCAN CONTEXT
}

\author{
H. Laachrate ${ }^{1, *}$, A. Fadil ${ }^{2}$, A. Ghafiri ${ }^{1}$ \\ ${ }^{1}$ Ben M'sik Faculty of Sciences, Av Driss El Harti, Sidi Othmane, Casablanca, B.P 7955, Morocco - (hibatoullah007, \\ a.ghafiri)@gmail.com \\ ${ }^{2}$ Hassania School of Public Works, Km 7 Route d'El Jadida, Casablanca, BP 8108, Morocco - fadil.abdelhamid@ gmail.com
}

KEY WORDS: Soil moisture, Rainfall, Microwave, SMOS, Hydrology, Remote sensing, Floods, Flood Monitoring, Morocco

\begin{abstract}
:
Soil moisture is an important parameter in many fields: hydrological, agricultural and even natural hazards monitoring (like floods). And, since soil moisture is crucial to flood monitoring a soil moisture spatial mission was launched in the 2nd November 2009: Soil Moisture And Ocean Salinity (SMOS). In this context, two Moroccan flood events are considered: November 2014 floods at Guelmim and Sidi Ifni and $23^{\text {rd }}$ February 2017 floods at Rabat and Salé. The methodology is based on the combination of the observation of two parameters: soil moisture (satellite data) and rainfall data (in-situ and satellite-based data) in order to have a vision of the flood risk in Morocco in the future with the comparison of Rainfall and soil moisture maps before and after the flood events. Among the main results, a strong relation between soil moisture and floods was detected for the November 2014 floods (for Guelmim soil moisture reached $0.6 \mathrm{~m} 3 / \mathrm{m} 3$ on 20 and 21 November 2014) and between Rainfall amount and floods for the 23 February 2017 floods (119 $\mathrm{mm}$ on the day of the flood event).
\end{abstract}

\section{INTRODUCTION}

Because of its geographical location and climate change, Morocco is a country easily exposed to extreme events such as drought and floods. Floods are one of the most devasting natural hazards. They can lead to a large human and economic damage. One of the most efficient method of flood monitoring and prediction is the use of the soil moisture (SM) as an important hydrological and climatic parameter of initial condition of soil. This parameter combined to rainfall can give us a quick prediction of an eventual flood. The retrieval of SM can be done within two main categories: in-situ and remote sensing. In this paper, we will choose the second one with Soil Moisture and Ocean Salinity (SMOS) satellite as data source. Some previous studies have used SMOS data for flood monitoring in a context other than the Moroccan one (AlvarezGarreton et al. 2015; Romanov et Khvostov 2015; Seo et al. 2017). Two examples of Moroccan floods will be studied: Guelmim and Sidi Ifni during November 2014 and Rabat-Salé on 23 February 2017. To observe the two floods events, we will make soil moisture and rainfall maps before, during and after the event and we will create soil moisture time series of the study area.

\subsection{Definitions}

1.1.1 Floods: According to the Centre for Research on the Epidemiology of Disasters (CRED) floods are classified as a Natural (Disaster group) and Hydrological (Disaster subgroup) Disaster. Within this classification four flood sub-type are listed: Coastal flood; Riverine flood; Flash flood and Ice jam flood.
Floods are defined in The Emergency Events Database (EMDAT) Glossary by: "A general term for the overflow of water from a stream channel onto normally dry land in the floodplain (riverine flooding), higher-than- normal levels along the coast and in lakes or reservoirs (coastal flooding) as well as ponding of water at or near the point where the rain fell (flash floods)." (EM-DAT 2018).

1.1.2 Soil Moisture: The SM that we will use as a parameter in our study is the volumetric $\left(\mathrm{m}^{3} / \mathrm{m}^{3}\right)$ water content of the first five centimetres of the soil. It can be defined as : the volume of water $(\mathrm{Ve})$ divided by the total volume of soil $\left(\mathrm{V}_{\mathrm{T}}\right)$ : $\mathrm{Ve} / \mathrm{V}_{\mathrm{T}}$ (Dissanska et al. 2010).

1.1.3 Rainfall: Rainfall or rain is a type of liquid form of Precipitation which is according to the Met Office "any form of water - liquid or solid - falling from the sky". It is the result of condensation of water vapour and precipitating (Met Office 2018). The unit of measurement of this parameter is millimetres (mm).

1.1.4 Water cycle: The water cycle includes different key processes such as precipitation (rainfall and other forms). Different variables are into this cycle such as soil moisture. The non-evenly distribution of the precipitation in space and time in addition to high levels of SM can easily increase the runoff and thus can lead to flood events (Sujay V. Kumar 2015).

We will use in our study of historical floods two key parameters: SM and Rainfall. Our context of study will be presented in the next section.

\footnotetext{
* Corresponding author
} 


\section{SOIL MOISTURE MAPS FOR FLOOD MONITORING}

\subsection{Context}

Morocco is a country located in the North West Africa in the subtropical zone. The climate varies depending on the region. Coastal areas have a temperate climate, while in the south and east of the country the climate is desert. The North's climate is Mediterranean and the West's one is oceanic. The climate also varies according to the seasons (DMN 2017). The climate map according to the National Direction of Meteorology (DMN) in Morocco is shown in the Figure 1 bellow.

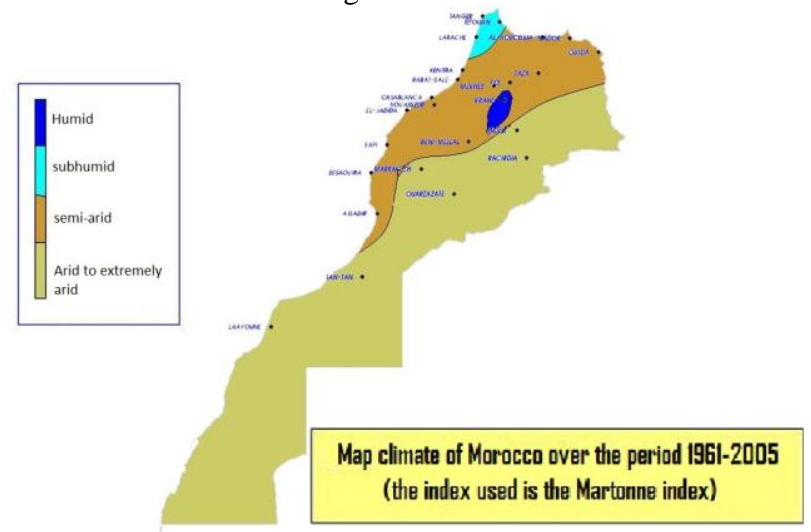

Figure 1. Moroccan climate map, translated from: (DMN 2017)

Floods are the second disaster with the highest mortality rate in Morocco after Earthquakes (DesInventar s. d.). According to CATastrophes NATurelles (CATNAT), Morocco has known 29 main flood events during the period from 2001 and 2017 (CATNAT 2017). Two cases are studied in this paper, but they are considered by CATNAT as three flood events since the first study case is split into two periods of flooding:

- $\quad \mathbf{1}^{\text {st }}$ study case: Our first case of study was during November 2014 at Guelmim and Sidi Ifni within two flood events: from $20^{\text {th }}$ to $24^{\text {th }}$ November 2014 and from $25^{\text {th }}$ to $30^{\text {th }}$ November 2014. These two flood events were catastrophic leading to 47 deaths and many other traumatised people psychologically and affected financially since buildings were damaged. In addition, the damage was assessed at more than 6 billion dirhams. Roads were cut, dikes broke, and power cuts affected a large part of the population (Zurich Insurance Company Ltd et Targa-AIDE 2015)

- $\quad 2^{\text {nd }}$ study case: The second study case was during the $23^{\text {rd }}$ February 2017 at Rabat-Salé. After a great amount of Rainfall accumulation, the two cities have known in $23^{\text {rd }}$ February 2017 floods leading to traffic jam

The study area concerns four Moroccan known cities: Guelmim, Sidi Ifni, Rabat and Salé. We will consider Rabat and Salé as one entity: Rabat-Salé since they are twin cities (with a very close geographic proximity). Guelmim $\left(28^{\circ} 59^{\prime} 17^{\prime \prime} \mathrm{N}, 10^{\circ} 03^{\prime}\right.$ $\left.27^{\prime \prime} \mathrm{W}\right)$ has an arid to extremely arid climate and whereas Sidi Ifni $\left(29^{\circ} 23^{\prime} \mathrm{N}, 10^{\circ} 10^{\prime} \mathrm{W}\right)$ and Rabat-Salé $\left(34^{\circ} 01^{\prime} 31^{\prime \prime} \mathrm{N}, 6^{\circ}\right.$ $50^{\prime} 10^{\prime \prime} \mathrm{W}$ ) have a semi-arid climate (DMN 2017).

\subsection{Data}

SM and Rainfall are two important parameters in flood monitoring. These parameters can be assessed by two categories of measurement methods: in-situ and remote sensing. In our study we have chosen the second type of retrieval with some insitu values for rainfall. In order to create SM maps, Rainfall maps and SM time series, we have used data sources from two missions: SMOS for SM and the real-time TRMM MultiSatellite Precipitation Analysis (TMPA-RT) for Rainfall (Daily accumulated precipitation in $\mathrm{mm}$ ). Two products are used for these two missions (1) for SMOS and (2) for TMPA-RT:

1. Global L3 Soil Moisture products, 3-days global map (CATDS 2016)

2. 3B42 RT Derived Daily Product (NASA Goddard Earth Sciences Data And Information Services Center 2018)

The following table (Table 1) includes the main characteristics of the used data:

\begin{tabular}{|c|c|c|}
\hline & 1 & 2 \\
\hline Name of the product & L3 SM 3 day & $\begin{array}{c}\text { TRMM_3B42R } \\
\text { T_Daily }\end{array}$ \\
\hline Satellite & SMOS & $\begin{array}{l}\text { TRMM and } \\
\text { other data }\end{array}$ \\
\hline Provider & CATDS & NASA \\
\hline Time aggregation & 3 days & 1 day \\
\hline Spatial resolution & $25 \mathrm{~km}$ & $25 \mathrm{~km}$ \\
\hline Format & NetCDF & NetCDF \\
\hline Projection & WGS 84 / & WGS-84 \\
\hline & $\begin{array}{l}\text { NSIDC EASE- } \\
\text { Grid 2.0 Global } \\
\text { (EPSG:6933) }\end{array}$ & $\begin{array}{c}\text { Geographic } \\
\text { lat/lon }\end{array}$ \\
\hline
\end{tabular}

Table 1. Characteristics of the SMOS (1) and TMPA-RT (2) used data

The SMOS satellite has a 2-3 days temporal revisit. For this reason, we have chosen to use a 3 days aggregation product. This CATDS: "Centre Aval de Traitement des Données SMOS" Level 3 product is calculated for each pixel in a way that when more than one value exists for the same pixel, the value of the best pixel is chosen (pixel with good quality of SM retrieval i.e. with the lowest DQX) (Kerr et al. 2013).

For the daily precipitation, we also used in addition to satellite data some in-situ data: Sidi Ifni (Infoclimat 2018) ,Guelmim (eltiempo 2018), Rabat-Salé (meteomanz 2018).

To generate SM and Rainfall maps with NetCDF data, we have used Panoply which is a Java application developed by National Aeronautics and Space Administration (NASA) and available in https://www.giss.nasa.gov/tools/panoply/download/. For the SM time series, we have used BEAM software provided by the European Space Agency (ESA) which has been replaced recently by SNAP.

The acquisition of SMOS imagery from the satellite is done by two types of orbit: ascending (satellite moving from the South to North and crossing the local equator at 6:00 a.m), descending (satellite moving from the North to South and crossing the local equator at 6:00 p.m) (ESA 2018). The ascending and descending orbits are processed separately. The choice of the best orbit is generally based on the lowest percentage of Radio Frequency Interference (RFI) contamination in the study area. The figure 2 shows RFI occurrences maps for both ascending 
(a),(c) and descending (b),(d) orbits for the dates: from $17^{\text {th }}$ November to $1^{\text {st }}$ December 2014 (a),(b) and for $23^{\text {rd }}$ February 2017 (+ or -7 days) (c),(d). In these maps we notice that for Morocco the RFI impact is low or non-existent for the second half of November 2014 where the flood events occurred and the same for 23 February 2017 for both ascending and descending orbits. This leads us to another criterion of selection: the soil in the morning is in a hydraulic quasi-equilibrium (Jackson 1980). Thus, measurement of the top $5 \mathrm{~cm}$ of SM of the ascending orbit are closer to ground measurement than those of the descending one (Leroux et al. 2014; Jackson 1980). And, that why we have chosen the ascending orbit in our study.

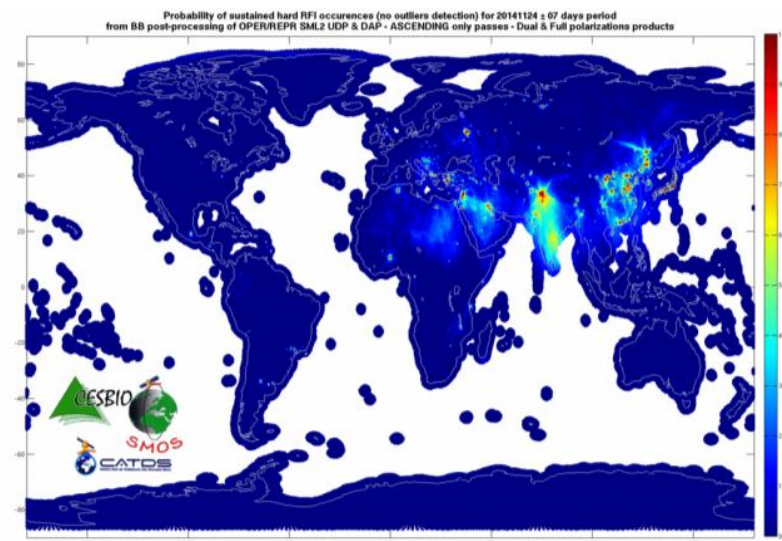

(a)

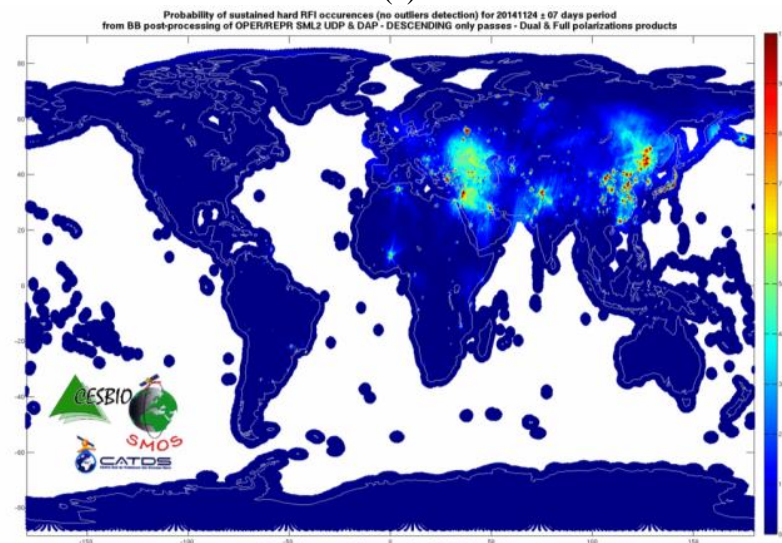

(b)

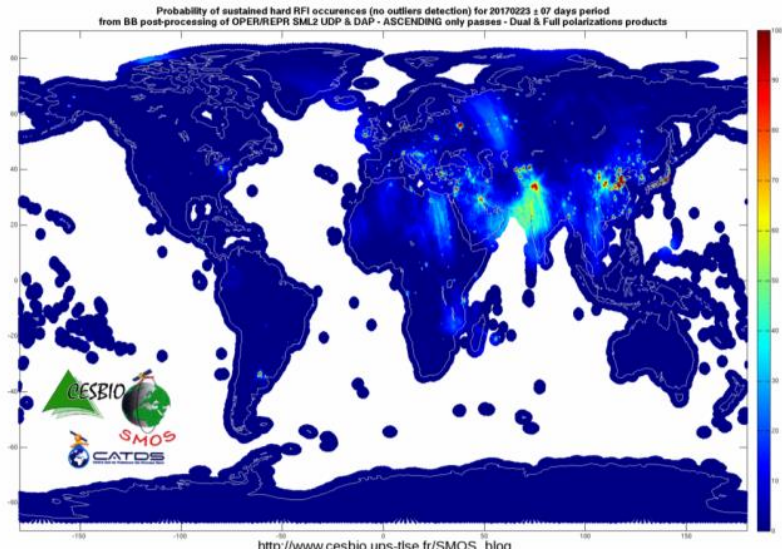

(c)

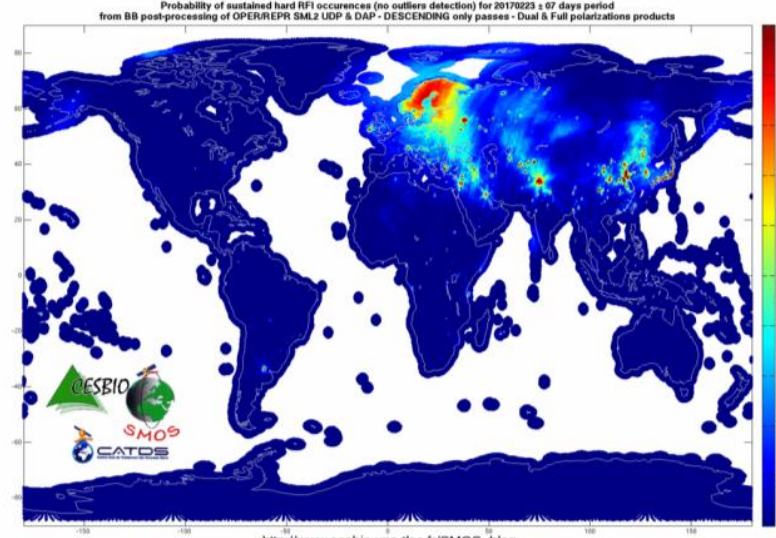

(d)

Figure 2. Probability of RFI occurrences from $17^{\text {th }}$ November to $1^{\text {st }}$ December 2014 for ascending (a) and descending (b) orbits and from $16^{\text {th }}$ February 2017 to $2^{\text {nd }}$ March 2017 (23rd February 2017 (+ or -7 days)) for ascending (c) and descending orbits

(d)

\subsection{Results}

2.3.1 Case of November 2014: As we have seen in the context section these floods were disastrous. They are classified as flash floods and were split into two periods: 1 - from $20^{\text {th }}$ to $24^{\text {th }}$ November 2014 and 2- from $25^{\text {th }}$ to $30^{\text {th }}$ November 2014. The figures 3 and 5 are Rainfall maps and the figures 4 and 6 are SM maps and the Figure 7 is a SM Time Series graph.

\section{- First period of rain (from $20^{\text {th }}$ to $24^{\text {th }}$ November):}

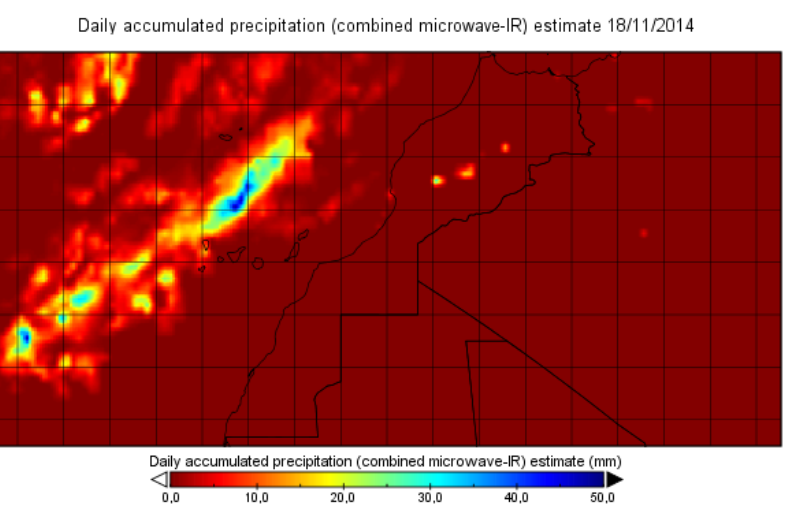

(a)

Daily accumulated precipitation (combined microwave-IR) estimate 21/11/2014

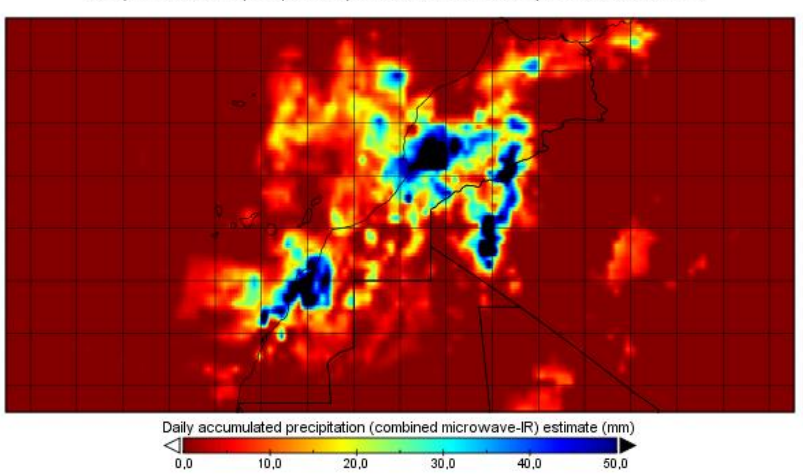

(b) 
Daily accumulated precipitation (combined microwave-IR) estimate 23/11/2014

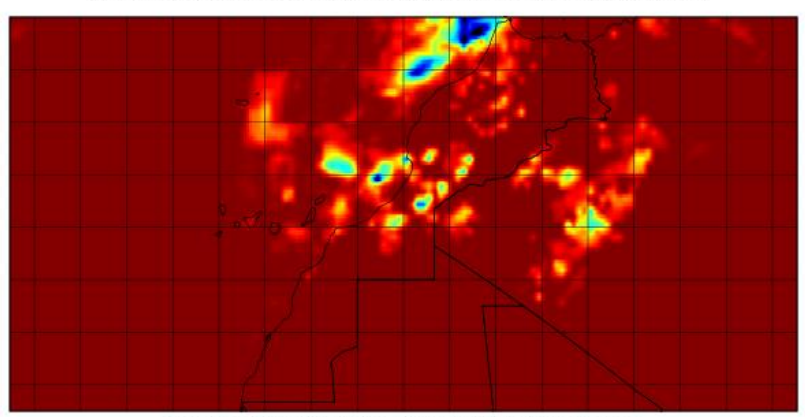

$\underset{0.0}{4}$

(c)

Figure 3. Rainfall maps before the event (a) and during the first period of rain (b), (c)

On 18 November 2014 (before flood events), the sky was clear in the Moroccan's Territory land and rainfall accumulation was $0 \mathrm{~mm}$ in Guelmim and Sidi Ifni for both satellite and in-situ data. During the first period of rain (from 20 to 24 November 2014) the precipitation maps show an increase in rainfall and daily accumulated precipitation - from satellite data - has reached: $16.2 \mathrm{~mm}$ (16.4 $\mathrm{mm}$ in-situ) on 21 November and $0 \mathrm{~mm}$ (11.1 mm in-situ) on 23 November at Guelmim. For Sidi Ifni, values are: $32.31 \mathrm{~mm}(25 \mathrm{~mm}$ in-situ $)$ on 21 November and 0 $\mathrm{mm}$ (11 mm in-situ) on 23 November. When satellite data don't give real or accurate values for a specific date, they can be replaced by in-situ data like the values on 21 November. Even if we have noticed an increase in daily precipitation we can't assume that this information lead directly to an inundation risk. We need to know the information about SM in the same period. SMOS Asc (17/11/2014-19/11/2014)


(a)

SMOS Asc (20/11/2014-22/11/2014)

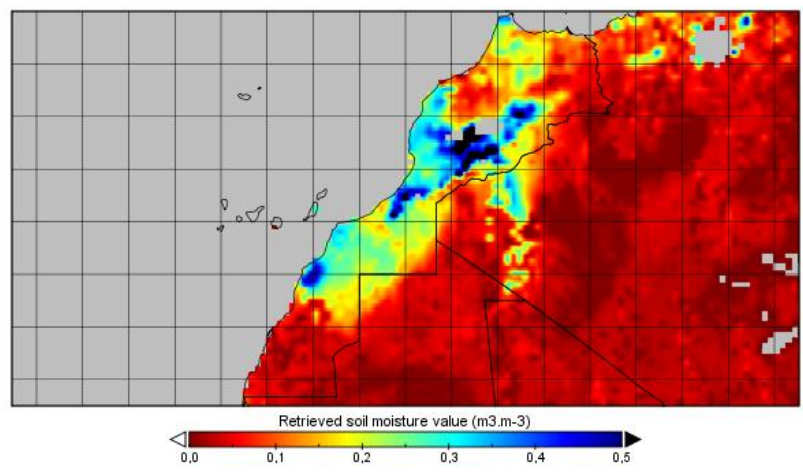

(b)
SMOS Asc (22/11/2014-24/11/2014)

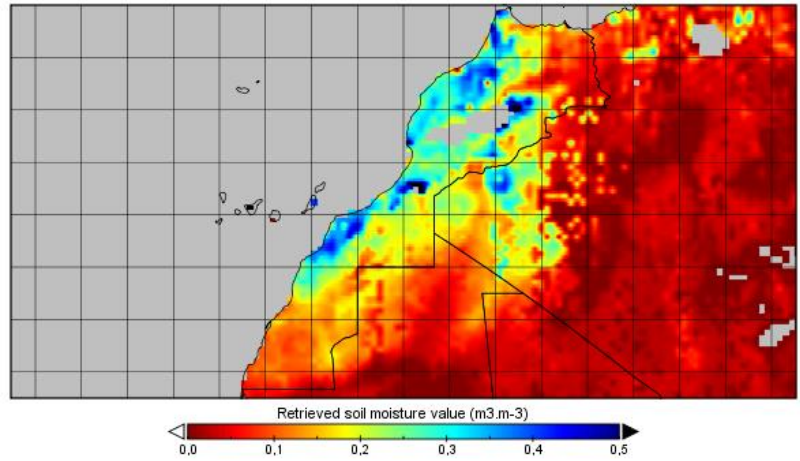

(c)

Figure 4. SM maps before (a) and during the first period of rain (b),(c)

The dates of rainfall maps (1-day temporal aggregation) are taken as the centre date of SM maps (3-days temporal aggregation). We can notice that before the flood event $(17 / 11 / 2014-19 / 11 / 2014)$ the sol was dry (red color) $0 \mathrm{~m}^{3} / \mathrm{m}^{3}$ at Guelmim (Figure 4.a). Then, the SM increased quickly to a very high value $0.61 \mathrm{~m}^{3} / \mathrm{m}^{3}$ for the interval: $20 / 11 / 2014-22 / 11 / 2014$ and then to $0.5 \mathrm{~m}^{3} / \mathrm{m}^{3}$ for the interval: $22 / 11 / 2014-24 / 11 / 2014$ This quick increase of the SM in addition to other hydrological parameters have led to floods in Guelmim and Sidi Ifni.

- Second period of rain (from $25^{\text {th }}$ to $30^{\text {th }}$ November):

Daily accumulated precipitation (combined microwave-IR) estimate 27/11/2014

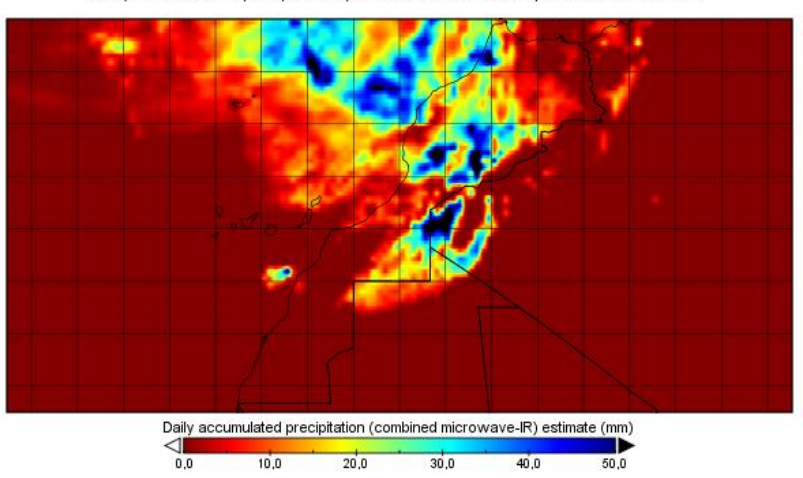

(a)

Daily accumulated precipitation (combined microwave-IR) estimate 29/11/2014

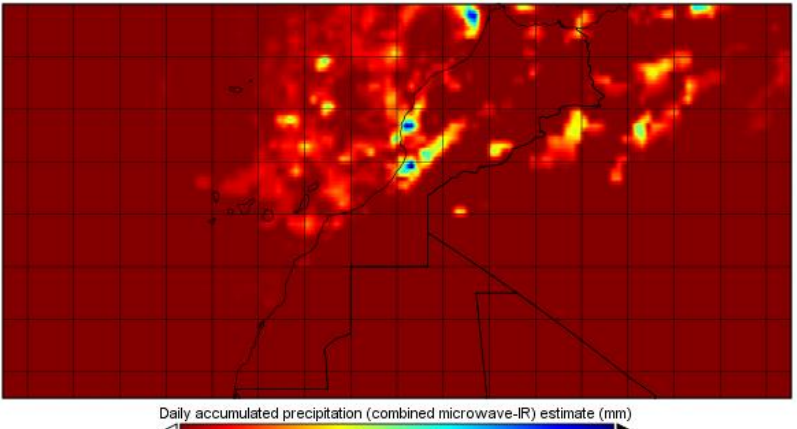

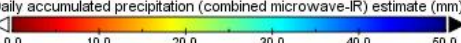

(b)

Figure 5. Rainfall maps during the second period of rain on 27 and 29 November 2014 
In the second period of rain, daily precipitation was $6 \mathrm{~mm}(13.1$ $\mathrm{mm}$ in-situ) on 27 November and $2.76 \mathrm{~mm}(32.6 \mathrm{~mm}$ in-situ) on 29 November at Guelmim. And, for Sidi Ifni, $2.28 \mathrm{~mm}(4 \mathrm{~mm}$ in-situ) on 27 November and $10.6 \mathrm{~mm}(24 \mathrm{~mm}$ in-situ) on 29 November. Floods occurred in the first period of rain and since another series of rain started. The floods continued.

SMOS Asc (26/11/2014-28/11/2014)

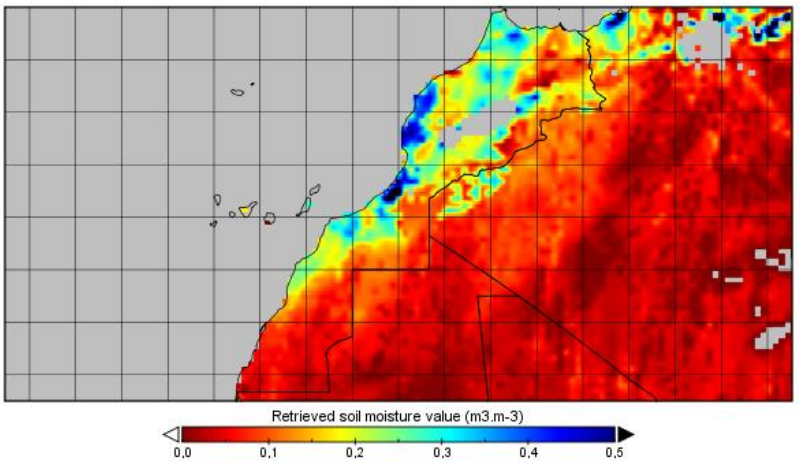

(a)

SMOS Asc (29/11/2014-01/12/2014)

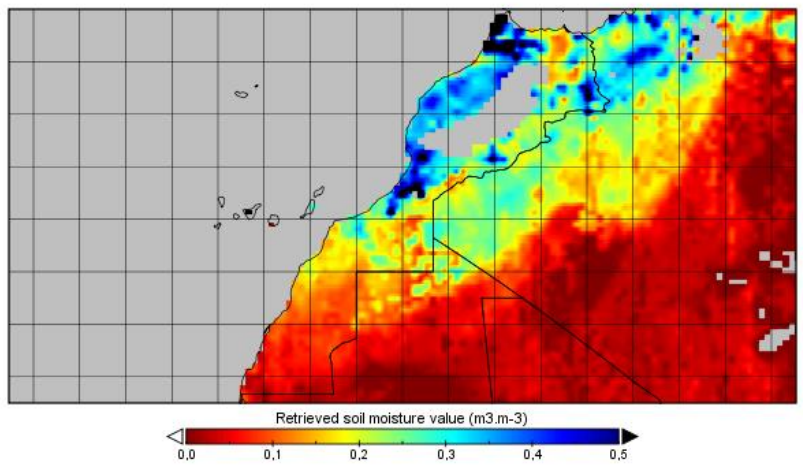

(b)

Figure 6. SM maps during the second period of rain on 27 and 29 November 2014

For the SM maps some data gaps are noticeable in the pixels located in mountainous zones because retrieval algorithms of passive microwave satellites like SMOS are generally affected by the soil topography (Mätzler et Standley 2000). During the second period of rain the SM values are still high $0.38 \mathrm{~m}^{3} / \mathrm{m}^{3}$ for the interval $26 / 11 / 2014-28 / 11 / 2014$ and $0.64 \mathrm{~m}^{3} / \mathrm{m}^{3}$ for the interval 29/11/2014-01/12/2014.After the first period of rain, the soil is still wet and other rainfall events occurred causing a soil saturation and then other flood events.

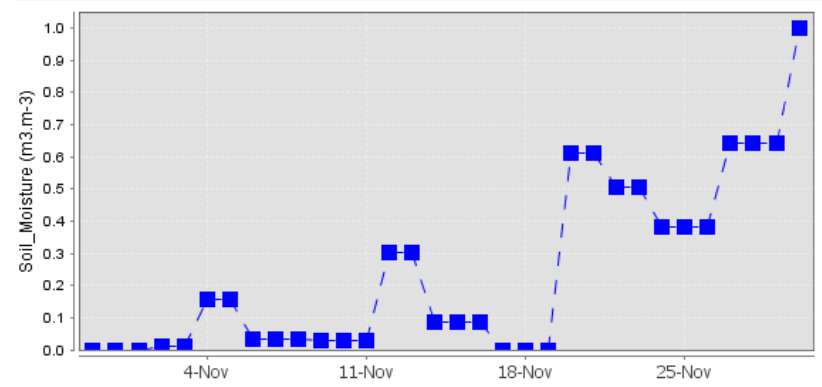

Figure 7. SM Time Series of Guelmim during November 2014

The figure 6 shows 2 maximum pics during the two periods of the flood events at Guelmim: on 20 and 21 November 2014 when the $\mathrm{SM}$ value reached $0.6 \mathrm{~m}^{3} / \mathrm{m}^{3}$ and on 30 November
2014 with a maximum of $1 \mathrm{~m}^{3} / \mathrm{m}^{3}$. The two pics are characteristic of the rain periods and the previous additional information about rainfall lead to conclusions about flood events.

2.3.2 Case of 23 ${ }^{\text {rd }}$ February 2017: At $23^{\text {rd }}$ February the two cities Rabat and Sale have lived floods triggered by great amount of Rainfall in a short period of time. The figure 8 concerns Rainfall maps and the figure 9 shows SM maps whereas the figure 10 is about Rainfall daily amount of the February month.

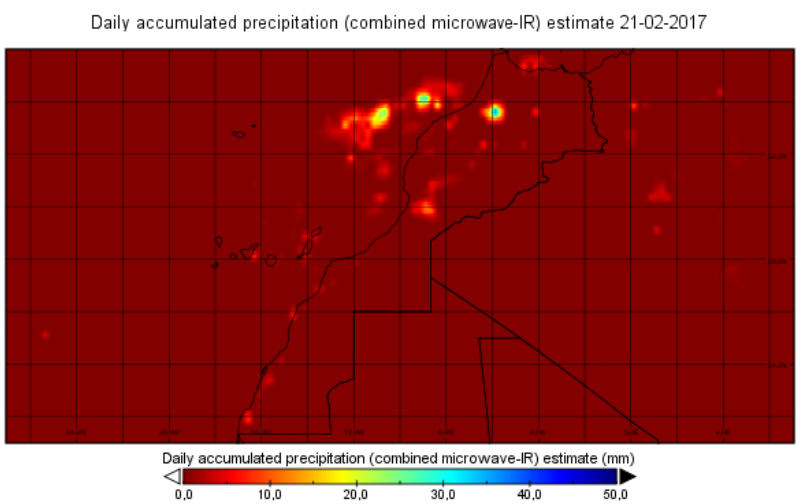

(a)

Daily accumulated precipitation (combined microwave-IR) estimate 23-02-2017



Daily accumulated precipitation (combined microwave-IR) estimate (mm)

(b)

Figure 8. Rainfall maps before (a) and during (b) the flood event

Before the flood event, on 21 February 2017 the sky is clear for Rabat-Salé with $0 \mathrm{~mm}$ (in-situ) of daily precipitation and in just few hours this parameter jumped to $119 \mathrm{~mm}$ (in-situ) on 21 February 2017. This lead us to classify this event not only as urban flood but also as flash flood due the high speed of this event.

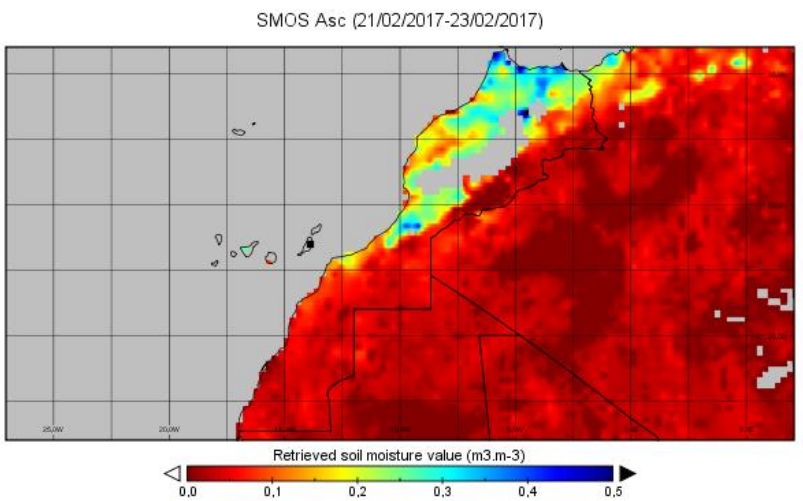


(a)

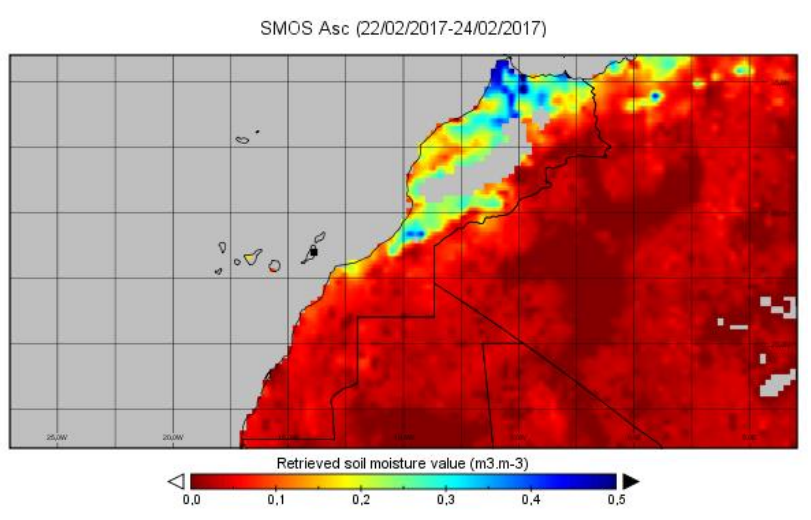

(b)

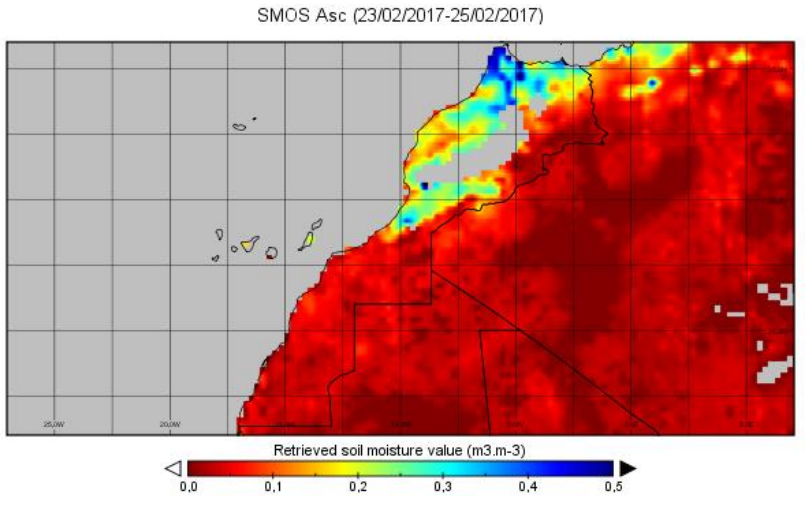

(c)

Figure 9. SM maps before (a), during (b) and after (c) the flood event

A general view of the three maps of the figure 9 leads us to the conclusion that before the event the soil was dry and that during and after the flood the soil is wetter. However, values of SM in Rabat-Salé during and after the event $\left(0.04 \mathrm{~m}^{3} / \mathrm{m}^{3}\right)$ don't express that floods occurred.

\section{Rainfall amount of Rabat-Salé station during February 2017}

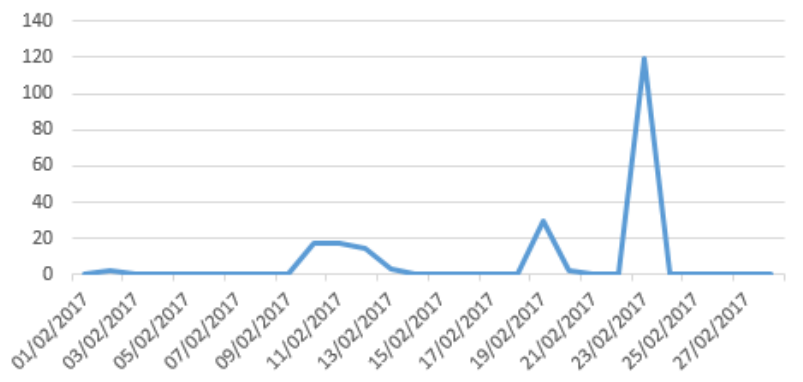

Figure 10. Daily precipitation Time Series of February 2017

Since we noticed that SM maps didn't give us a clear view about the floods that occurred we established a daily precipitation time series of the February 2017 month (Figure 10). And, we noticed an obvious maximum pic on 23 February 2017 leading us to know the event trigger which the very high value of the precipitation $119 \mathrm{~mm}$.

\section{CONCLUSION AND PROSPECTS}

Floods are one of the most devasting extreme events. They are caused by excessive water availability and can have great negative impact leading to natural, societal and economical damage (Wanders et al. 2014). In this paper, we have studied two main flood events: Guelmim and Sidi Ifni during November 2014 and Rabat-Salé on 23 February 2017. For our study, we have used satellite data from SMOS, TRMM and other data. We have also used some in-situ data for precipitation. For November 2014 floods, SM values has reached, for example, at Guelmim $0.6 \mathrm{~m}^{3} / \mathrm{m}^{3}$ on 20 and 21 November 2014 and $1 \mathrm{~m}^{3} / \mathrm{m}^{3}$ on 30 November 2014. For 23 February 2017 floods, SM values couldn't lead us to the conclusion the existence of flood events but the rainfall amount that reached $119 \mathrm{~mm}$ on the day of the event was obviously the cause of floods. We have noticed the strong relation between SM and floods with the November 2014 floods and a direct relation between the quick increase of Rainfall amount and floods in the 23 February 2017 floods. However, if we want to conduct a predictive study of flood forecasting it is necessary to have a more complex model with more parameters and a clearer SM-Rainfall-flood relation.

\section{ACKNOWLEDGEMENTS}

SM data were obtained from the «Centre Aval de Traitement des Données SMOS »(CATDS), operated for the «Centre National d'Etudes Spatiales » (CNES, France) by IFREMER (Brest, France).

\section{REFERENCES}

Alvarez-Garreton, C., D. Ryu, A. W. Western, C.-H. Su, W. T. Crow, D. E. Robertson, et C. Leahy. 2015. «Improving Operational Flood Ensemble Prediction by the Assimilation of Satellite Soil Moisture: Comparison between Lumped and Semi-Distributed Schemes ». Hydrology and Earth System Sciences 19 (4): 1659-76. https://doi.org/10.5194/hess-19-16592015.

CATDS. 2016. «CATDS-PDC L3SM Aggregated - 3-day, 10day and monthly global map of soil moisture values from SMOS satellite ». CATDS (CNES, IFREMER, CESBIO). https://doi.org/10.12770/b57e0d3d-e6e44615-b2ba-6feb7166e0e6.

CATNAT. 2017. «CATastrophes NATurelles .net - Accueil». 2017. https://www.catnat.net/.

DesInventar. s. d. «DesInventar - Profile». Consulté le 28 octobre 2018. https://www.desinventar.net/DesInventar/country_pro file.jsp? countrycode $=$ mor\&lang $=\mathrm{EN}$.

Dissanska, Maria, C Paniconi, Monique Bernier, et INRS-ETE. 2010. Étude du potentiel des données polarimétriques RADARSAT-2 pour le suivi de l'humidité du sol en milieu agricole (campagne 2008 sur la plaine Campidano, Sardaigne, Italie). http://espace.inrs.ca/1671/1/R001194.pdf.

DMN. 2017. «DMN ». 2017. www.marocmeteo.ma.

eltiempo. 2018. «Weather ». 2018. https://en.eltiempo.es.

EM-DAT. 2018. «EM-DAT | The international disasters database ». 2018. https://www.emdat.be/.

ESA. 2018. «SMOS - eoPortal Directory - Satellite Missions ». 2018. https://earth.esa.int/web/eoportal/satellitemissions/s/smos.

Infoclimat. 2018. «Infoclimat - la météo en temps réel: observations météo en direct, prévisions, archives 
climatologiques, photos et vidéos...» 2018. https://www.infoclimat.fr/.

Jackson, Thomas J. 1980. «PROFILE SOIL MOISTURE FROM SURFACE MEASUREMENTS » 106 (mars): 81-92.

Kerr, Y.H, E Jacquette, A. Al Bitar, F Cabot, A Mialon, P Richaume, A Quesney, et L Berthon. 2013. «CATDS SMOS L3 Soil Moisture Retrieval Processor Algorithm Theoretical Baseline Document ATBD ». Technique. CATDS.

Leroux, Delphine J., Yann H. Kerr, Ahmad Al Bitar, Rajat Bindlish, Thomas J. Jackson, Beatrice Berthelot, et Gautier Portet. 2014. «Comparison Between SMOS, VUA, ASCAT, and ECMWF Soil Moisture Products Over Four Watersheds in U.S. » IEEE Transactions on Geoscience and Remote Sensing 52 (3): 1562-71. https://doi.org/10.1109/TGRS.2013.2252468.

Mätzler, C., et A Standley. 2000. «Technical note: Relief effects for passive microwave remote sensing: International Journal of Remote Sensing: Vol 21, No $12 » . \quad 2000$. http://www.tandfonline.com/doi/abs/10.1080/014311 60050030538 .

Met Office. 2018. «Rain». Met Office. 2018. https://www.metoffice.gov.uk/learning/precipitation/r ain.

meteomanz. 2018. «Datos meteorológicos de SYNOPS/BUFR - Predicciones GFS/ECMWF - Meteomanz.com». 2018. http://www.meteomanz.com/.

NASA Goddard Earth Sciences Data And Information Services Center. 2018. «TRMM (TMPA-RT) Near Real-Time Precipitation L3 1 day 0.25 degree x 0.25 degree V7 ». NASA Goddard Earth Sciences Data and Information Services Center. https://doi.org/10.5067/TRMM/TMPA/DAY-E/7.

Romanov, A. N., et I. V. Khvostov. 2015. « Microwave Remote Monitoring of Altai Catastrophic Flood Dynamics Using SMOS Data ». IEEE Geoscience and Remote Sensing Letters $12 \quad$ (10): 2036-40. https://doi.org/10.1109/LGRS.2015.2444592.

Seo, Dugwon, Tarendra Lakhankar, Brian Cosgrove, Reza Khanbilvardi, et Xiwu Zhan. 2017. «Applying SMOS Soil Moisture Data into the National Weather Service (NWS)'s Research Distributed Hydrologic Model (HL-RDHM) for Flash Flood Guidance Application ». Remote Sensing Applications: Society and Environment 8 (novembre): $182-92$. https://doi.org/10.1016/j.rsase.2017.09.002.

Sujay V. Kumar. 2015. «Introduction to Land Data Assimilation Systems (LDASs) ». 